\title{
Natural Gas Pipelines Leakage, Toxicity and its Safety Measures
}

\author{
Papiya Mandal*, Rashmi Misra and Poonam Kumari \\ CSIR-National Environmental Engineering Research Institute, India
}

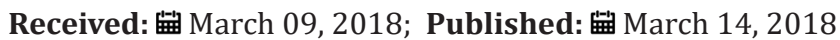

*Corresponding author: Papiya Mandal, Delhi Zonal Centre, CSIR-National Environmental Engineering Research Institute, Delhi, India

\section{Abstract}

A fugitive emission of natural gas during the extraction of oil and gas and its transportation through the pipeline has potential threat to the environment. Natural gas (NG) is the mixture of hydrocarbon gases consisting primarily of methane and other varying hydrocarbons, a small fraction of carbon dioxide, hydrogen, nitrogen, hydrogen sulphide and rare trace gases like helium, neon, xenon etc. The colorless and odorless NG has a wide range of applications as a cleaner fuel. The rapid urbanization, industrialization and economic growth all over the world demand the increasing transportation capacity of NG. Though the transportation pipeline are laid with well-equipped sophisticated technology and leak detection sensors, however still there are risk factor associated for leakage of the gases and explosion. The impacts of man-made disaster are in terms of deaths, injury, losses in economics, property and also having the adverse effect on ecology. The integrity of the NG pipeline system can be achieved by adopting continuous sophisticated up gradation technology. It also requires operation and maintenance of the pipeline at regular interval.

Abbreviations: NG: Natural Gas; CNG: Compressed Natural Gas; PNGRB: Petroleum and Natural Gas Regulatory Board

\section{Introduction}

\begin{tabular}{|c|c|c|c|}
\hline \multirow{3}{*}{ Methane $\left(\mathrm{CH}_{4}\right)$} & Components & Structure & $\begin{array}{l}\% \text { in } \\
\text { NGs }\end{array}$ \\
\hline & Methane & $\mathrm{CH}_{4}$ & $60-90$ \\
\hline & Ethane & $\mathrm{C}_{2} \mathrm{H}_{6}$ & $0-20$ \\
\hline \multirow[b]{3}{*}{ Ethane $\left(\mathrm{C}_{2} \mathrm{H}_{6}\right)$} & Propane & $\mathrm{C}_{3} \mathrm{H}_{8}$ & $0-20$ \\
\hline & Butane & $\mathrm{C}_{4} \mathrm{H}_{10}$ & $0-20$ \\
\hline & $\begin{array}{l}\text { Carbon di } \\
\text { oxide }\end{array}$ & $\mathrm{CO}_{2}$ & $0-8$ \\
\hline \multirow{2}{*}{$\begin{array}{r}\text { Propane }\left(\mathrm{C}_{3} \mathrm{H}_{8}\right) \\
\text { Butane }\left(\mathrm{C}_{4} \mathrm{H}_{10}\right) \\
\text { Condensates } \\
\left(\mathrm{C}_{5} \mathrm{H}_{12}-\mathrm{C}_{10} \mathrm{H}_{22}\right) \\
\end{array}$} & Oxygen & $\mathrm{O}_{2}$ & $\begin{array}{l}0- \\
0.20\end{array}$ \\
\hline & Nitrogen & $\mathrm{N}_{2}$ & $0-5$ \\
\hline \multirow{2}{*}{$\begin{array}{r}\text { Nitrogen }\left(\mathrm{N}_{2}\right) \\
\text { Carbon Dioxide }\left(\mathrm{CO}_{2}\right) \\
\text { Hydrogen Sulphide }\left(\mathrm{H}_{2} \mathrm{~S}\right) \\
\text { Helium (He) }\end{array}$} & $\begin{array}{l}\text { Hydrogen } \\
\text { Sulphide }\end{array}$ & $\mathrm{H}_{2} \mathrm{~S}$ & $0-5$ \\
\hline & Rare Gases & $\begin{array}{l}\mathrm{He}, \mathrm{Ne}, \\
\text { Xe etc. }\end{array}$ & $0-2$ \\
\hline
\end{tabular}

Figure 1. The composition of natural gas and its composition in percentage

Urbanization, industrialization and economic growth of India are exerting the tremendous pressure on the natural resources. This increases the frequency and intensity of disaster, especially man-made disaster in the developing country like India due to large population density, borderline economic status of the vulnerable population and inadequate adjustment of capacity building. Sometimes, a natural disaster may not be averted; however manmade disasters can definitely be controlled by taking adequate 
preventive actions and preparedness. The leakage of NG through pipeline is man-made disaster, which is most common and has major problem in industrial, commercial and residential sectors in India. NG has wide application as cleaner fuel in power driven vehicles like CNG (compressed natural gas) buses, cars, etc. The chemical formula of $N G$ is $C_{n} H_{2 n+2},(n=1,2$.. etc.). The components, structure and its percentage in NG is shown in (Figure 1). NG mainly consists of a high percentage of $\mathrm{CH}_{4}$ gas (60-90\%). Odorless, invisible $\mathrm{CH}_{4}$ gas is highly combustible and clean burning in nature, and highly explosive under pressure. NG easily cannot mix-up and disperses in the atmosphere, which may lead to suffocation as well as fire explosion. Though NG is highly useful but their leakages have serious toxicological impacts on environment and human health. So it is essential to control the leakage of NG to protect people, ecology and environment.

\section{Natural Gas -Production, Transmission \& Distribution (Sector-Wise Demand and Production of Natural Gas)}

India has limited reserves of NG. The production of $\mathrm{NG}$ in India in the month of January, 2017 was 2,738 million standard cubic meter (mmscm) which was higher by $11.9 \%$ as compared to January, 2016 (2,447 mmscm) [1]. Sector wise demand, production, transmission and distribution process of NG in India is shown in (Figure 2). The increasing demands for uses of NG at various sectors include electricity generation, fertilizer production, commercial, small, medium and large scale industries and residential sector. The extraction of NG, treatment and transportation through pipelines are tedious and costly phenomena. NG is extracted through gas wells in raw form and oil and water portions are separated. Oil components are treated in a gas processing plant in which nonhydrocarbon gases are removed.
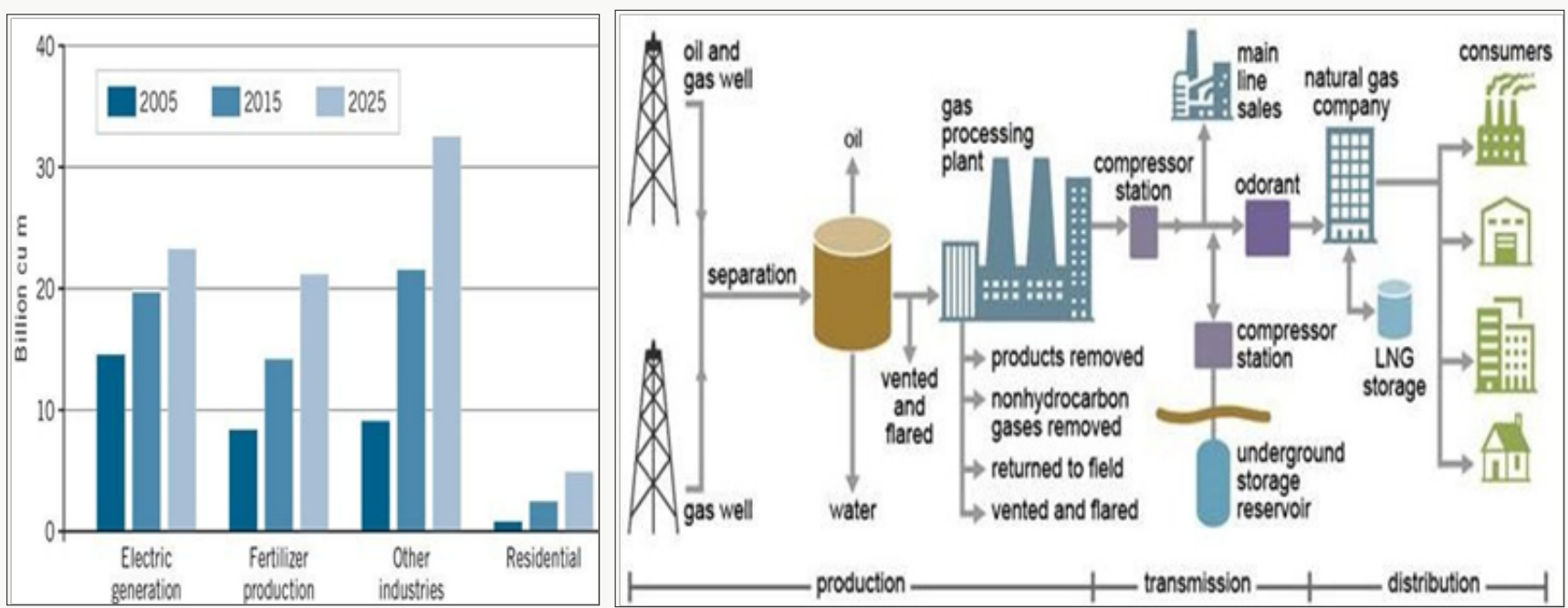

Figure 2. Sector wise demand, production, transmission and distribution process of NG in India

NG is colorless, odorless and flammable gas, which are compressed to liquid at very low temperature. Odorant like ethyl mercaptan are mixed with gases so that leakage can easily detect through pungent smell installing a gas leakage detection system in a critical zone or sector is another alternative to identify the leakage of NG from storage and pipelines.

\section{Intricacies of NG Pipeline Network System}

The pipelines of NG are mostly laid in the combination of underground and overhead network system. It consists of compressor stations, isolation valves, relief valves, leak detection system, receivers, control system and sometimes casting sleeves under road and rail crossing. NG pipeline network system are damaged due to external interference, corrosion, construction defect/ material failure, hot tap made by error, ground movement etc [2]. Transportation of NG requires provision for protection of hazardous properties of NG, quantity of NG to be released and its effects and periodical maintenance of pipeline- accessories. The intensity of damage due to leakage of NG would lead to fire hazard. Fire hazard causes burning of gas/oil, which produces heat, light and often smokes (mixture of soot particle, toxic gases, water vapor etc.) and flames. This type of critical situation arises when NG is mixed with appropriate concentration of air or oxygen in the presence of ignited source in atmospheric environment. The primary failure cause distribution in percentage is shown in (Figure 3). Fire and explosion causes accidents mostly in refineries, petrochemical, gas processing, terminal, and offshore facilities which are attributed due to mechanical issues, process upset, and operational error. Flammable material releases in the form of a fireball, pool fire, flash fire, flare or jet fire, and an unconfined vapor cloud explosion [3]. The similar types of anthropogenic disaster effect in term of the injury, loss of life, damage of property, ecology and environment. Few major disasters occurred till date since 1984 due to gas/oil leakage and fire hazards in India is presented in (Table 1). 


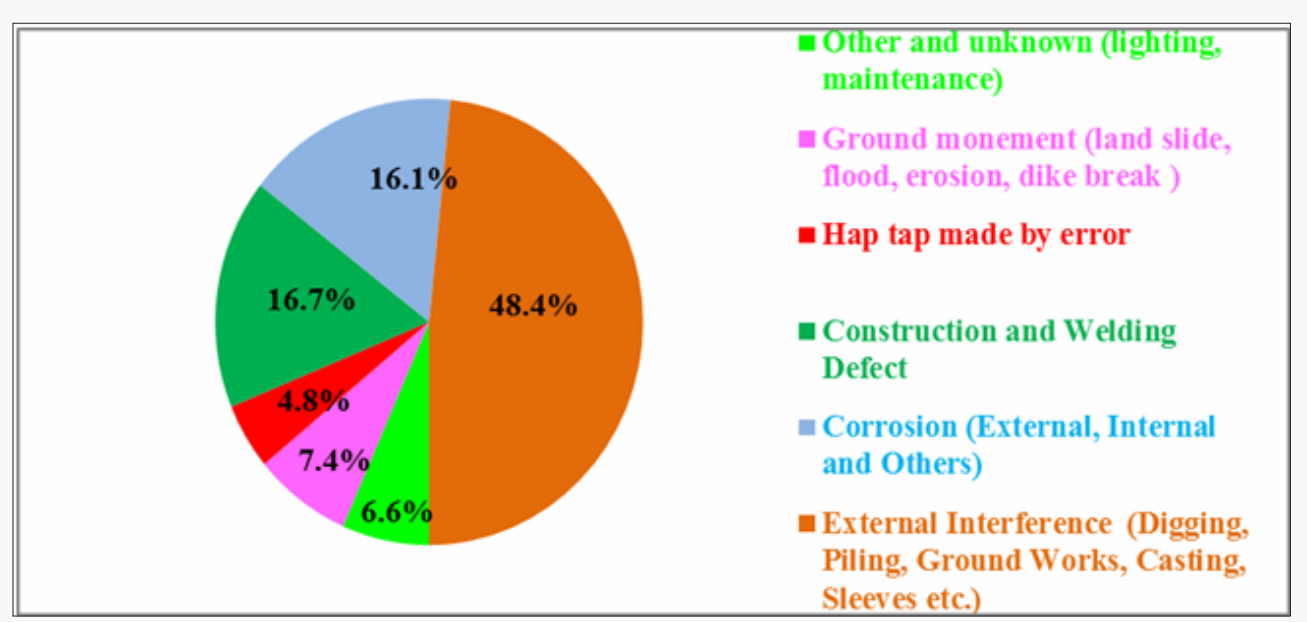

Figure 3: Primary failure cause distribution in percentage.

Table 1: Few Major Disaster Due Gas/Oil Leakage and Fire in India

\begin{tabular}{|c|c|c|c|c|}
\hline Year & Place & Incident & Chemical & Toxicological Effects \\
\hline 1984 & $\begin{array}{l}\text { Bhopal, Madhya } \\
\text { Pradesh }\end{array}$ & Gas leakage & Methyl isocyanate & $\begin{array}{l}\text { A. Death of thousands of people due to choking, } \\
\text { reflexogenic circulatory collapse and pulmonary } \\
\text { oedema. } \\
\text { B. Peri- and neonatal death rates increased. [9] }\end{array}$ \\
\hline 1988 & Mumbai, Maharashtra & Refinery fire & Oil & $\begin{array}{l}\text { Hydrocarbon vapor clouds form and ignited } \\
\text { leads to human death and injuries on site [10] }\end{array}$ \\
\hline 1990 & $\begin{array}{l}\text { Nagothane, } \\
\text { Maharashtra }\end{array}$ & Leakage & Ethane, propane & $\begin{array}{l}\text { Vapor cloud formation occurs due to leakage in } \\
\text { pipeline carrying ethane and propane gas leads } \\
\text { to } 31 \text { people set to fire and death [11] }\end{array}$ \\
\hline 1994 & Asansol, West Bengal & Fire & Methane & - \\
\hline 1995 & $\begin{array}{l}\text { Pasarlapudi,, Andhra } \\
\text { Pradesh }\end{array}$ & Blasting of pipeline & Natural gas & $\begin{array}{l}\text { Massive damage to ONGC occurs due to fire } \\
\text { catch in oil well for } 60 \text { days[12] }\end{array}$ \\
\hline 1997 & $\begin{array}{l}\text { Visakhapatnam, } \\
\text { Andhra Pradesh }\end{array}$ & Refinery fire & Liquid petroleum gas & $\begin{array}{l}\text { A. } 70 \text { people killed as gas leak and mixed with } \\
\text { clouds which pour down in form of rain. } \\
\text { B. This gas on other hand catches fire } \\
\text { [13] }\end{array}$ \\
\hline 2003 & Vellore, Chennai & Explosion & Explosives & - \\
\hline 2009 & Jaipur, Rajasthan & Fire & Oil & $\begin{array}{l}12 \text { died and around } 200 \text { people injured when } \\
\text { IOC depot catches fire [14] }\end{array}$ \\
\hline 2013 & $\begin{array}{l}\text { Visakhapatnam, } \\
\text { Andhra Pradesh }\end{array}$ & Refinery explosion & Hydrocarbons & $\begin{array}{c}01 \text { killed and } 39 \text { injured when gas leakage } \\
\text { catches fire. The under construction cooling } \\
\text { tower on site collapse leading to major damage. } \\
\text { The pungent smell spread due to leakage causes } \\
\text { eye irritation and respiratory problem causing } \\
\text { suffocation [15] }\end{array}$ \\
\hline 2014 & $\begin{array}{l}\text { Nagaram village, } \\
\text { Andhra Pradesh }\end{array}$ & Blasting of pipeline & Natural gas & $\begin{array}{l}14 \text { people killed and } 15 \text { injured due to blast in } \\
\text { pipeline belong to GAIL. This cause heavy noise } \\
\text { pollution and fire engulf a entire village. Birds } \\
\text { and domestic animals are also the victim of this } \\
\text { disaster [16] }\end{array}$ \\
\hline 2014 & Raipur, Chattisgarh & Gas leakage & Methane & $\begin{array}{l}\text { Metane gas leakage from the pipeline of water } \\
\text { pump house in Bhilai Steel Plant leading to } \\
\text { death of } 06 \text { worker and } 40 \text { injured [17] }\end{array}$ \\
\hline
\end{tabular}




\begin{tabular}{|c|c|c|c|c|}
\hline 2016 & $\begin{array}{l}\text { Ankapura Village, } \\
\text { Karnataka }\end{array}$ & Gas leakage & Liquid petroleum gas & $\begin{array}{l}\text { The gas leakage occurs due to small hole in } \\
\text { pipeline and spread to nearby village. The } \\
\text { people from village are shifted to safer places } \\
\text { and effects of gas reduced by spraying water to } \\
\text { avoid serious damage [18] }\end{array}$ \\
\hline \multirow[t]{2}{*}{2017} & Shivrajpur, Kanpur & Gas leakage & Ammonia gas & Ammonia gas released from cold \\
\hline & & & & $\begin{array}{l}\text { storage building used for stocking of potato } \\
\text { harvest. This gas explodes due to high pressure } \\
\text { leading to causalities [19] }\end{array}$ \\
\hline 2017 & Belur Town, Karnataka & Gas leakage & $\begin{array}{l}\text { Chloro (methyl) } \\
\text { diphensylsilance }\end{array}$ & $\begin{array}{c}\text { Due to excessive leakage and spread of chlorine } \\
\text { gas the people suffer from breathing problem } \\
\text { and hospitalized at Belur [20] }\end{array}$ \\
\hline
\end{tabular}

\section{Remedial Measures for the Safety of Ng Pipelines}

The statuary compliances are already established by Govt. of India for safety of NG pipelines in terms of construction, operation and maintenance, which has to be followed strictly by every oil and gas company $[4,5]$. The statuary compliances are as below

a) Petroleum and Natural Gas Regulatory Board (PNGRB) Act 2006

b) Guidelines for Environmental clearance specially of new projects - 1981

c) The Environment (Protection) Act 198

d) Water (Prevention \& Control of Pollution) Act 1974

e) Air (Prevention \& Control of Pollution) Act 1981

f) The Petroleum and Mineral Pipelines (Acquisition of Right of Users in Land) Act 1962

g) Manufacture, Storage \& Import of Hazardous Chemical Rules - 1989
h) National Highway Act 1956
i) Railways Act 1989
j) OISD (Standard 226 - Natural Gas Transmission Pipeline and City Gas Distribution Network) k) ASME 31.8 (Gas Transmission and Distribution Piping
System)

\section{Safety for Leakage of NG Pipelines}

Safety from leakage of NG pipelines is the most essential requirements. Safety can be maintained by taking following precautions in India.

a) Pipeline is having three layers of polyethylene external coating. Every pipeline is properly marked which provides information about the transported materials and emergency phone number?

b) Liquid pools, discolored of pipe materials, bubbling in wet or flooded area, or fire coming from the ground or pipe is a indicator of a pipeline leakage. Immediate identification of pin holes, leakage from valves, cracking of pipes is to be made for safe transportation of NG.

c) Sometimes sound of leaking of gas from pipelines can make possible by listening or hearing a quiet hissing of loud roar. It also depends on the volume of gas leaking from the pipelines.

d) An unusual smell, petroleum odor, or gaseous odor will sometimes serve as a indicator to detect pipeline leakage. Mercaptans due to its odorant properties added in NG for detection of leakage.

e) Installation of casing pipes at all the crossing and highway crossing as per International Standards.

f) Automatic fire detection and suitable fire extinguisher installed at the critical sections.

g) Provision for cathodic protection system for pipeline against corrosion.

h) Corrosion sensing probes for monitoring external corrosion rate.

\section{Various Phases to Minimize Process Leakage and Fire}

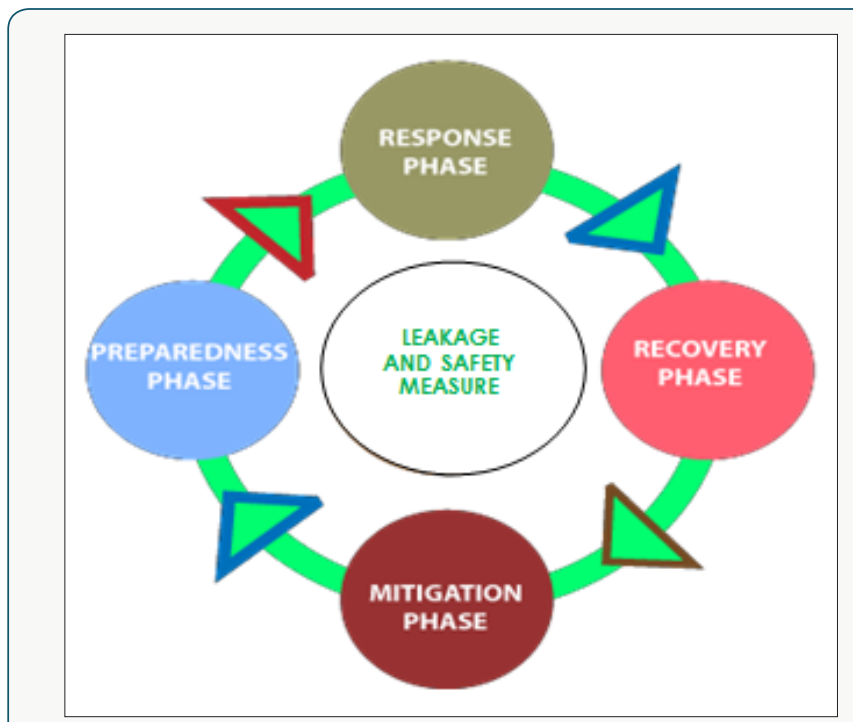

Figure 4. The various phases of leakage and safety measures 
The leakage of NG and fire hazard are preventable but it requires routine checkup and maintenance of the NG processing and its transportation system. Various phases viz preparedness phase, response phase, recovery phase and mitigation phase to minimize process leakage and fire safety measures are shown in (Figure 4).

\section{Toxicological Impacts of Natural Gas Leakage}

$\mathrm{NG}$ is an asphyxiant that reduce oxygen in air causing suffocation. The varying toxicological adverse effects on environment and human health of NG are as follows

Environmental Effects: NG leak and explode to produce large water vapor leading to humid atmosphere. This is a favorable condition for growth of multiple viruses and bacteria. It also produces toxic chemicals fumes and greenhouses gases may cause serious damage to various environmental entities [6].

Human Health Effects: NG is an asphyxiant it may cause unconsciousness, brain injuries and even death due to oxygen depletion. The combination of various chemicals may lead to various diseases. These gases have both short term and long term effects on human health which directly correlates with the nature of leakage, combination of gases contaminants, dispersion area of gas, concentration etc. The following are few common human health impacts of NG leakage.

Short Term Health Effects: Respiratory Tract Disorders (shortness of breath, coughing, wheezing, runny nose, respiratory irritation, asthma, bronchitis, pneumonia), Cardiovascular System Disorders (heart disease), Gastrointestinal System Disorders (diarrhea), Immune System Disorders (immune suppression), Dermal Disorders (eye irritation, skin rashes, chemical sensitivity), Psychiatric Disorders (depression, memory loss), Nervous System Disorders (fatigue, headache) and Other (weight loss) [7-20].

Long Term Health Effects: Cancer (lung and bronchus, skin, prostate, bladder, esophagus and stomach, pancreas, intestinal, leukemia, multiple mycelia, secondary cancers), genotoxicity, teratogenecity, the multiple organ disorders such as respiratory tract, gastrointestinal, dermal, musculo-skeletal, psychiatric, nervous, endocrine/nutritional/ metabolic, haematopoetic, genitourinary systems.

\section{Conclusion}

Natural Gas (NG) pipeline distribution system needs to be more skillful in India. The occurrence of anthropogenic disaster due to leakage and explosion of gas pipelines are recurrent in country. The integrity of NG pipeline distribution system may be achieved through continuous up gradation from initial stage of site selection, design of pipelines, commissioning, operation and maintenance as per the guidelines of Government of India. Technological up gradation, staff training for standard operating procedure, inspection, maintenance, fire safety and emergency preparedness enhances the safety of pipeline distribution system which may improve overall safety of the pipelines networking system to great extent. Toxicological effects of natural gas leakage and emission may be avoided by eliminating uses of these gases for general purposes.

\section{References}

1. Economics Times Report (2017) India.

2. EGIG Report (2015).

3. OH\&S Report (2010).

4. S. P. Garg (2012) Safety of Natural Gas Pipelines. Gail Report.

5. United Nations Report (2014).

6. Harmful Effects of Natural Gas in Your Home.

7. Erkekoglu P, Giray BK (2010) The Toxicological Outcomes of Oil Spills and Oil Fires. Fabad J Pharm Sci 35:45-58.

8. Health Problems Related to Natural Gas Leaks.

9. Eckerman Ingrid (2005) The Bhopal Saga-Causes and Consequences of the World's Largest Industrial Disaster. India: Universities Press 113(5): A344.

10. R K Saha, S Ray, B R Maity, S Ganguly, D Bhattacharya, et al. (2012) Petroleum refining and petrochemical based industries in eastern India, Allied Publishers Limited.

11. D Bradley,GMakhviladze,PSunderland,FTamanini,V Molkov (2013) Fire andExplosion Hazards.

12. GAIL pipeline blast: CoastalAndhra people seek propersafety measures.

13. MS Shanker (1997) It Rains Liquid Petroleum.

14. 12 dead, over 200 injured in Indian Oil depot fire in Jaipur.

15. One dead, 39 injured in Vizag refinery blast.

16. 14 killed, 15 injured in gas pipeline blast in Andhra Pradesh.

17. Gas leak in Chhattisgarh's Bhilai steel plant, 6 killed, 40 injured.

18. Gas pipeline leak in Hassan village.

19. Kanpur: Ammonia gas leak causes explosion in cold storage; five killed, several still trapped.

20. Chlorine gas leak on Belur outskirts. 


\section{(a) \\ This work is licensed under Creative Commons Attribution 4.0 License}

To Submit Your Article Click Here: Submit Article

DOI: 10.32474/MAOPS.2018.01.000110

Assets of Publishing with us
- Global archiving of articles
Petrochemical Sciences

